\title{
THE IOWA GAME BOOK OF GEORGE E. POYNEER
}

\author{
Edited by James R. HaRlan
}

More common to the East and South than to the Middle West, the game book is a log, as it were, of the strictly shooting or hunting record of the writer. It is a diary in the special sense that it exclusively devotes itself to one subject and one subject alone, the game record of the hunter.

Probably the most interesting lowa game diary in existence is the Game Book of George E. Poyneer, of Clinton, the deceased father of Fred J. Poyneer, present member of the Iowa State Conservation Commission. While the record begins in 1869, in Penn Yan, New York, and the last entry is at Clinton, Iowa, September 9, 1877, just the Iowa portion is here given.

It is to be remembered that this record was kept during market hunting times, when thousands upon thousands of Iowa game birds and animals were being hunted for shipment to Eastern markets for sale. But George E. Poyneer was not a market hunter. In fact he was one of the first in the Middle West to agitate for a closed spring season on migratory birds.

Employed in the office of C. Lamb \& Sons, lumber millers, a successful man and a leader in his community, George Poyneer loved to hunt. He was human. His diary, August 23, 1874, reads, "I killed four on the first rise. It was delightful. The dog acted well." This semi-spontaneous entry may well be judged the key to the whole log.

The ornithologists will notice in this journal 30 passenger pigeons killed May 31, 1874. The passenger pigeon was extinct in Iowa in 1903, and extinct in the world in 1914. 
They will notice 17 woodcocks killed July 3. This bird is rare in Iowa now. He will notice an entry of 73 prairie chicken killed August 22. Prairie chicken now rarely nest in Iowa. He will notice wood duck, plover, ruffled grouse, swans, sand hill cranes, and other now rare birds, legally and ethically hunted.

The hunter will remark the use of sculling, stools, decoys, of packs, and other terms, some obsolete, some still in use. The marksman will see and understand, " 33 birds with 35 shots," "Birds in fine condition and layed well," "Jack and I tied with 50 (birds) each. The most interesting incident of my shooting career," "Birds scarce and very wild," "Used No. $4 \mathrm{~s}$ and 5 dram P 2 W." The hunter will go on some of the delightful hunting excursions with George Poyneer and his friends.

The game technicians and administrators will notice the above points and many others. "I got disgusted at shooting ducks from the wild work of green-horns. There was no show at the ducks." The scarcity of rabbits, with only 3 taken in 1874, a year when the diarist took a total of 546 separate pieces of game. Many will understand "We killed 9 birds quicker than lightning, and down came an old Granger on horseback, and oh, how mad!" They will notice, "Complaint of scarcity of prairie chicken," with a day's entry of 22 prairie chicken, 2 woodcock, and 5 wood ducks killed. They will notice, "There was no night shooting and I haven't seen any here."

The general reader will see early lowa hunting as it was universally enjoyed but seldom recorded. Without further comment we submit Geo. E. Poyneer's "Game Book," for Iowa, exactly as it came from his hand.

\section{March 31/74}

\section{At Chinton Iowa}

Ben Woodward \& I went on board the good steamer Chauncy at 10 P. M. put on boat and traps ${ }^{2}$ and next morning at $4: 30 \mathrm{~A}$. M. we were landed on an island in the Mis-

\footnotetext{
'Ben Wroodward was a famous duck shooter of eastern Iowa, well known throughout mid-west shooting circles.

${ }^{2}$ Equipment and shooting gear.
} 
sissippi in Dark Shoot we built a fire got our breakfast and as soon as day light come we launched our boat went up the river a little ways Ben got a sitting shot in some Pintails and made a very long shot at a Mallard with his Remington. Wind blowing very hard and indications of storm. we started down the river. Not many duck moving. Down near Running Slough we began seeing more. Ben did some fine work sculling on Mallard and Pintail I did the shooting. Hard snow storm came on made it very unpleasant. When we were near Running Slough I did a good thing on some Red Head. Then we struck in slough did not get much shooting until we got half way down. We landed went to a house and cooked some coffee. "How is it Ben." Had some fine shooting at Teal \& Blue Bill and some Mallard. Good many Pin tail \& Mallard going into lake near Turkey Slough but we could not do anything with them. Teal most plenty saw some comical maneuvering in a large flock. Did wicked work on a flock of Blue Bill. Flock of Prairie Chicken flew over us as we were running down the slough got home about $71 / 2$ P. M.

\section{Duck.}

\section{April 17/74}

Got up at $5 \AA$. M. went up on bottoms above the house thinking I might find some Snipe and saw enough. there was a nice show of birds. I had some fine sport and thinking my watch had run down I hurried back to the house to find it only $61 / 2 \AA$. M. The birds had just come in layed first rate it being an icy \& frosty morning I could have made a big bag if I could have had the time Ben killed 6 Snipe on 16 inst(?)

13 Snipe

Apl 18

My shoot set the boys in the fever Ben came up at 7 A. M. we went over the same ground the birds were scarce and wild some body had been there besides me we got back at 10 A. M.

\section{April 23/74}

\section{Snipe}

Went up on the bottom after work found Col Noyes 
there did not see but very few birds and they were wild 1 Snipe

April 30

Went up after work on the Snipe ground saw a few birds they layed quite well I did not manage them right. They were in very nice order

July 4

\section{Snipe}

Ben his brother in law and I started at 3 A. M. went up the river to Turkey slough very warm day I did some poor shooting saw a few wood duck

July $14 / 74$

12 Woodcock 1 Duck.

Juckett $^{3}$ and I went down on the island did not start until near 4 P. M. We had a splendid shoot Don acted well hit my birds very hard one in particular could not find but $\alpha$ wing tip

July 21

11 Woodcock 1 Pigeon

Ben and I went down on the island Woodcock very scarce did not see but one saw quite a number of duck 3 Wood duck

Aug. 1

Went over by the ferry landing saw a good many shore birds and a few duck.

Aug. 5

l Woodcock 1 Wood duck

Juckett and I started at $31 / 2$ A. M. went down on the island had a nice little shoot saw quite a good many duck More Mallard than I expected to see got back at 8 A. M.

Aug. 15

5 Wood duck 3 Mallard

In company with Henry Woodman and Dick Hawthorn we drove out to Dick Lyons left at 1 P. M. and got on the ground at 3 P. M. had a delightful ride. I used Don and

\footnotetext{
aFrank Juckett, boyhood hunting companion of Poyneer in the East, came west with the latter to Clinton. Juckett and Poyneer both moved to Cedar Rapids at a later date and hunted together as old men.
} 
he got away and flushed some chickens in a corn field I had one shot and missed them then went down in the bottom come onto a large fine covey they were fine birds the dog acted very bad and run them on got up three other packs and the shooting was delightful but the dogs acted very bad my first chicken shoot and I vote them the birds to kill' we had a fine tea at Lyons Charlie hunted with us got home at 11 P. M. well pleased

\section{Aug. 23}

\section{Chickens}

Got a livery horse Geo Gardener and I drove out to Lyon's found Charlie waiting for us we started as soon as I got there we found a fine pack of chickens just below the house in the corn they all got up at once I got down three Don acted well we got up one other fine brood I killed 4 on the first rise it was delightful the dog acted well had a fine meal at Lyons in the evening Got home in good season

\section{Aug. 30}

\section{Chickens}

Warm day went down on Beaver Island went into Rice slough a few duck and saw more Snipe than I had seen

\section{Sept. 3}

\section{Ducks 12 Snipe}

Left the office at $41 / 2$ P. M. went down on Beaver in Rice slough a good many duck went out had a nice little shoot

\section{Sept. 5}

$$
8 \text { Ducks }
$$

Went down on Beaver Game scarce

2 Ducks 1 Snipe

Sept $7 \& 15$

Beaver Island

$$
5 \text { Duck } 1 \text { Snipe }
$$

Sept. 20

Henry Bonney and I started for the Meradoshas at $3 \AA$.

4Excellent sporting birds.

"Meradosha is a marsh on the Illinois side of the River at Clinton. Iocally famous as an excellent hunting area, it was at one time drained, but is stil good for shooting. 
M. got there in good season and found it to be a great resort for ducks found lots of Snipe and upon the whole had a fine day got home $91 / 2$ Don did some good retrieving and acted nicely on Snipe.

Sept. 24

\section{Duck 23 Snipe}

Gliem [?] Wells and I started for the Meradosha at $3 \AA$. M. had a miserable boat but we got there and found lots of shooters in the afternoon the wind blew pretty hard which made it all the better for shooting had some fine fun at the Snipe Charlie Mills shot first rate we cooked some game and had a good time and a hard pull home.

\section{Oct. 4}

\section{Ducks 46 Snipe}

Started at 3 A. M. for the Dosha alone used Jucketts boat and got there long before light very warm day and lots of shooters I got disgusted at shooting at ducks from the wild work of green horns" there was no show at the ducks so I went at the Snipe I expected to find them very thick but the water had gone down and they were scarce I stopped shooting at noon and started for home. Saw 1 Partridge ${ }^{\gamma}$

\section{Snipe 2 Duck 1 Quail}

Oct 11

Thought I would not start until after breakfast it was windy and cloudy just the day for ducks Juckett and I went over in the Cat tail and there was lots of Ducks got shooting near $10 \mathrm{~A}$. M. I had fine fun at the Blue Wing teal had hard luck on large ducks but a good time in general There was no night shooting and I haven't seen any here" 30 Ducks

Oct 18

Jucket and I started out early it was very foggy the sun came out warm no day for ducks Juckett went home early I went out East of the Ferry landing to warm to do

sInexperienced huntsmen, shooting while the ducks were still too high and out of range.

TProbably refers to a ruffed grouse.

sight hunting, especially for wild turkeys, and, in the eastern states for passenger pigeons, was a sport Poyneer did not find practical in Iowa. 
much walking found one covey of quail they were to small had a little fun with the chickens killed one in the morning while on my duck stand

\section{Duck 1 Quail 3 Chickens}

\section{Oct 25}

Ham Potter took me down near Camache and I came up the bottom. a beautiful day. Saw quite a number of Mallard in a slough could not get to them. found some snipe around the edges they were very fat. Don did not act well on some chickens found one covey of Quail he did quite well. He pointed a chicken beautifully

\section{Snipe 6 Quail 1 Chicken [illegible]}

Jucket and I went out to Dick Lyons. expected to get some fine shooting near Goose Lake' but the weather moderated and our shoot was a failure a great many ducks flying in the mornings but were wild. Lafe [Lamb] ${ }^{10}$ and Ben made a big bag a few days ago We were out two days killed

Nov. 1

\section{Ducks \& some Snipe}

Lower end of Beaver Island. ${ }^{11}$ weather very warm to pleasant for ducks all sitting in the river

9 Ducks

Nov. 8

Lower end of Beaver Jucket \& I weather too fine 8 Ducks

Nov. 15

Lower end of Beaver with decoys the sun bothered me badly in the morning. I never saw ducks come to stools ${ }^{12}$ any better did not shoot very good used the single gun and made some long shots. I am satisfied with good decoys fine shooting can be had here.

26 Ducks

\footnotetext{
'A nearby lake now partially drained, but still good for duck shooting.

${ }^{10}$ Lafe Lamb was George Poyneer's employer, owner of a lumber mill at Clinton.

11An island on the Mississippi River close to the Illinois shore.

12 Decoys.
} 
Nov. 22

Foggy and unpleasant prospects of rain all the sloughs on Beaver island frozen up. Duck in large flocks saw an immense flock in Island below Beaver put in decoys but they did not come back

Nov. 26

6 Ducks

Went west of Lyons with Dick Hawthorn did not find any quail

Dec. 6

2 Rabbits

Crossed the bridge with Dash and went down East of Ferry landing. The old dog did fine after I showed him what I wanted. Staunch as a rock fine ranger and sure to make an extra dog 14 shots

Dec. 13

12 Quail

Jucket and I crossed the river in a boat near the Ferry landing. I got lost from him. I went South did not find but one bevy of quail. Old dog acted fine.

Dec. 20

5 Quail 1 Rabbit

Went over in Illinois with Old Dash nearly east of Fulton did some tall walking before I found the birds had hard luck in marking them down. Old dog did well in finding bevys but it was hard work for him to find wounded birds. I got up 5 Bevys all nice birds.

23 Quail

Total Game for 1874

Ducks

Snipe

182

Woodcock

24

Quail

Chicken

40

Pigeons

Rabbits

Squirrel 


\section{5}

\section{January 3}

Very cold day. I was foolish enough to start out found three bevies but I was so cold I could not shoot got home $21 / 2$ P. M.

\section{March 28, 1875}

\section{Quail}

Jucket and I went across to Beaver Island. Ice in the Sloughs \& Lakes saw quite a good many duck flying. Ice out of upper end Goose Lake a good many Blue Bill in I used my single gun and made some very good \& some very poor shots one very long one on Sheldrake ${ }^{13}$

\section{Ducks}

\section{April 1}

Jucket and I went across to the Ferry landing very few duck flying very windy and heavy rain came on. Ice began running on the way back got up snipe

\section{Ducks}

\section{April 2}

I went across the river very early intended to use stools froze up so hard could not get in ${ }^{14}$

1 Brant

\section{April 4, 1875}

We did not get off as early as we intended went to the lower end of Beaver Island the duck were flying thick before we got stools out set them on the East side of Lower Goose. Blue Bill and Red Head were flying thick but they did not see the stools very well at first until sun got up we had glorious shooting until $11 \AA$. M. I did most of the shooting Juckets gun did not shoot very well got home at 6 P. M. Used No. 4s 5 dram [?] P 2 W $^{16}$

\section{Ducks 1 Pigeon}

Got up at 6 A. M. went up on the bottom after Snipe used Old Dash got up two or three they were very wild. Juckett up yesterday morning killed 7

\section{Snipe}

\footnotetext{
13 Sheldrake is the present-day name given to Mergansers, but in the 1870 's the word commonly referred to shovelers or spoonbills.

14Ice or frozen marsh areas too hard for the boat to penetrate.

is Size and weight of shot used, together with the brand marks.
} 
April

Got livery horse took old Dash and started for Goose Lake bottom. saw a good many Brant \& Geese flying got on the ground $101 / 2$ A. M. Birds scarce and very wild frost last night a great deal ice in the ground and very hard walking worked hard until 4 P. M.

26 Snipe 11 Plover $^{16} 3$ Ducks

Went up and waked Juckett we went down on the bottom and had a splendid shoot got back to the office $9 \mathrm{~A}$. M. I had

\section{Snipe}

Took Eds horse went out on the bottom very warm then went out to Harts Mill Pond and went around Camanche worked hard.

\section{Snipe}

Jack Anderson Frank E \& I went to Goose Lake bottom very cold riding we had a merry time going out we found a good many birds below the road walking very hard birds in fine condition and layed well Dash made several points I shot badly in the afternoon got tired out. We shot about 4 hours and when we came to count game Jack \& I tied on 50 each The most interesting incident of my shooting career

\section{Snipe}

Jack Anderson killed 6 Snipe Weight 29 oz. ${ }^{17}$

Chas. Wells and I went to Goose Lake bottom weather very threatening. began raining when we first got on the ground birds had about all left those we found were wild and very fat. found some very fine ground on west side of Creek below the road. Saw several Prairie Chickens nest. Dash pointed them well. Charlie made some very nice shots.

May $31 / 75$

$$
25 \text { Snipe }
$$

Jucket and I went on Beaver Island 30 Pigeons $^{18}$ clear.

${ }^{16}$ Which one of the four important kinds of plovers referred to here is not iv Unusually heavy weight for snipe. 
July 3

Juckett and I left the office at 2 P. M. and went on Beaver Island water very high did not find any birds until we got into head of Upper Goose then we found them quite plenty had a splendid shoot got back at 6 P. M. I used Dash

\section{Woodcock}

July 13

Juckett and I went over the above grounds did not find scarcely any birds

\section{Aug. 1}

\section{Woodcock}

Chas. Wells and I started for Goose Lake at $8 \AA . M$. We had a nice [?] lively team. got to hunting at 10:30 windy and pleasant we found two broods of birds above the road I killed 10 out of one brood on first rise it bothered Chas to hit them went below the road in the afternoon and had some splendid shooting found two broods in the bottom in very wet ground

\section{Chickens}

\section{5}

Juckett and I went down on Beaver prospecting. Went in a dry slough at the upper end of Goose found Wood cock in very high grass Juckett used his Pointer Bob

\section{Woodcock}

Aug. 20

Oscar Morton Will Young and I arrived in Colo ${ }^{18 n}$ a little after 2 P. M. got ready and drove north an elegant day but birds scarce hunted over a considerable ground 5 I. [?]

\section{Chickens}

21

Anderson, Austin \& Wells came in on the midnight train we got off quite early and went N. W. elegant weather. farmers acted mean. Mr. Sonay in particular. saw quite

18Passenger pigeons. These birds were in those years extensively shot in Iowa and elsewhere as "market birds," and shipped in large quantities to eastern cities and dealers in such quality of game meat. Most of the river cities and many inland towns such as Waterioo and Fort Dodge had local dealers.

18aColo, on the Chicago, Northwestern line indicates another train trip to reach good hunting territory. 
a good many ducks ate dinner near Cunninghams then drove N. W. had some splendid shooting Just at night Jack \& I drove 3 large packs ${ }^{10}$ off one stubble down onto a piece of rolling prairie and such elegant shooting I never saw [Jack found (?) me?] I missed two shots in all day I bagged 35 . Got lost in the woods.

55 Chickens

August 22/75

We went Northwest again I got into a pack early in the morning had $\alpha$ fuss with $a$ Granger $^{20}$ but killed about all his birds went out the farthest we had been all Prairie and what a delight as far as the eye could reach in some directions without seeing a house saw some Sand Hill Cranes they looked like giraffes to $\mathrm{me}^{21}$. I did some strong walking we ate dinner with a decent farmer he showed us where to find some birds Jack raised an immense pack they went right out into the open prairie and what splendid shooting there was 20 in the pack we killed 18 of them. I did some very clean shooting on Old cocks. from the last nights experience we hurried toward home ${ }^{22}$ Jack and I went across a piece we killed nine birds quicker than lightning and down came an old Granger on horse back and oh how mad

\section{Chickens}

23

Oscar \& Will went home at midnight we took Sankie [?] and went south good looking ground but birds scarce found a nice lot in the afternoon we found three nice packs near together I did some wild shooting got careless Joe did well in finding \& holding came near getting lost on the Praries

\section{Chickens}

Oct. 3

Juckett and I went to be Meradosha expected a big

¿9"Pack" refers to a family or brood group, the birds all of an age.

20 This game book was kept in the days when the Patrons of Husbandry or the "Grangers" were active as social and political forces in the agrarian life of the country, especially the middle west. Granger here means a farmer, a word commonly applied to the organization due to the name given the local unit of the order.

${ }^{21}$ Present day hunters report the same impression.

22 Poyneer and Anderson got lost. 
day on Snipe especially. Charlie rode down shooting poor more [?] ducks-before [?]

Oct. 10

\section{Ducks 14 Snipe}

Well, Jucket and I went to the Meradosha. Juckett went up above the point had lots of shooting but did poor killing. Charlie and I had some fine shooting a good many birds flying.

\section{Ducks 8 Snipe}

17 Anderson and self started at three o'clock for the Meradosha quite windy we made $\alpha$ draw [?] ${ }^{23}$ with our boat and did not get to shooting until after 7 o'clock very plenty in the morning. Did some fair work on Teal very windy.

Lafe [Lamb] and Charlie [Elmerdorf] up the river had some good shooting. Saw Mat Temple at the mouth of the river.

\section{Ducks}

Lafe and I went down on lower Goose used decoys. One Canvas back came in but would not come to stool got back to the office at $101 / 2$ A. M.

\section{Oct. 24}

\section{Ducks}

Bob Huffman Chas. Wells \& I went up the Meradosha above where I had been very warm to much so for good shooting the point was a good place for large ducks. Juckett came up on the opposite side and waded across much fun for us. Bob [dog] had rather watch the hogs. [?] Charlie and I went down on my old stand for night shooting they came in pretty well. I made a hansome double on Mallard. Mosquitoes very troublesome Juckett killed goose.

31

\section{Duck 7 Snipe}

Juckett and I went to the Meradosha water very low left boat at the R R Bridge and walked up to my old ground everything froze up. 5 Swan were sitting out in the middle

23 Drag, over a sandbar. 
ice thick enough to hold up a Mallard very few flying started for home near noon found quite a good many coming in at the first bend did some very fine long shooting

Nov. 4

16 Ducks 2 Snipe 2 Chickens

Took boat and went down to lower end of Beaver Island used Decoys

\section{Nov. 7}

$$
5 \text { Ducks }
$$

Juckett \& I went to the Meradosha water very low and few ducks used decoys at the second bend more Green Wing Teal than anything came back early.

\section{Ducks}

Nov. 11

Lafe and I went on the lower end of Beaver Island used decoys mostly Blue Bill flying

14

\section{Ducks}

Wm. Huffman Juckett \& I went to Meradosha very few ducks principally Green Wing Teal water very low

Nov. 21

6 Ducks 1 Snipe

Juckett and I over in Illinois did not find but two bevy Quail I was using Wells Parker and did some poor shooting When coming home made a hansome double on a pair of Blue Bill

Dec. 12

$$
5 \text { Quail } 2 \text { Ducks }
$$

Juckett and I over in Illinois found one bevy of Quail east of the Ferry landing and used them up badly Dash \& Bob did some nice work. I had a hard time killing my first Partridge but succeeded

1 Quail 9 Partridge 3 Rabbits

Total Game Killed, 1875

Brant

Ducks

Snipe 


$\begin{array}{lr}\text { Chickens } & 171 \\ \text { Woodcock } & 30 \\ \text { Quail } & 14 \\ \text { Partridge } & 1 \\ \text { Pigeons } & 31 \\ \text { Plover } & 11 \\ & \\ & 705\end{array}$

1876 Feby 28

Juckett and I went on Beaver Island rained in the morning Took the Retriever Frank Very few duck more sheldrakes than anything. Ice out

\section{Ducks}

March 5

Rained most all the forenoon. Juckett \& I went down on Beaver Island near 1 P. M. Saw quite a good many Blue Bill flying over the East side of bridge

\section{Ducks}

7

Juckett and I went down on Beaver very cold and few ducks Used stools in lower Goose Good many shelldrakes flying

12 Ducks

March 12/76

Got up at 3 A. M. wind in north and cold. Juckett \& I went to the Meradosha. Sailed most of the way very unpleasant Went up above Willow Island thought we would have some good shooting put out stools all the duck that were flying came over one flock Canvas back turn in I killed one Juckett did most of the shooting

\section{Ducks}

19

Juckett \& I started out early with the intention of going to the Dosha but it began raining and hailing we stopped in lower goose Beaver Island very stormy two flocks of Canvas back came to the stools they came in fine style we killed 6 of them there was no duck flying so we picked up and went to the Dosha. They had been flying thick but stopped when we got there 
Juckett and I up on the bottom found one Snipe and killed him

\section{Snipe}

Jack Anderson and I drove out to Goose Lake we went below the road in the forenoon drizzled most all the time birds were very wild. Went above the road in the afternoon birds were scattered found where they had been very plenty on the west side in a meadow no birds below the road on west side Lafe and Charlie up at Hansons Used Frank

\section{Snipe}

Juckett and I drove out to Hansons pleasant morning quite a good many Brant flying got on the ground early. The Gages came out there was but few birds. Juckett went way up near the lake. he found more birds I did some poor shooting when we came to dinner he lead me a good many. In the afternoon we drove down south on the ground Jack and I were on I did some good shooting killed 16 straight and 17 out of 18. Bob did some nice work

July 4

Juckett and I took team and went to the Dosha prospecting $^{24}$ went up near the middle crossing saw a good many Quail they came back across the country saw some partridge. Owing to the high water everything was covered. Dash did some retrieving

\section{Woodcock}

11

Juckett and I on Beaver Island to much water

3 Woodcock

Aug 4

Juckett and I went to the Dasha prospecting

11 Huffman and I on Beaver Island

3 Ducks

Aug 18

Juckett and I drove out to Hansons 4 dogs we worked

24Prospecting for game in the Meradosha marshes. 
all day very hard got up three kinds of chickens ${ }^{28}$ and quite a good many old ones. found two Woodcock out in the middle of the bottom. played [illegible] trick on the Wood duck. Dug out a cow that was mired and nearly dead. John acted pretty well he stood it better than all the dogs.

The complaints come of the scarcity of Chickens ${ }^{20}$

22 Chickens 2 Woodcock

5 Wood duck

Aug. 25

Strong and I went to Meradosha left boat near the mouth could not get in up on south side opposite Willow point some Geese came out. I waded across to the point. Did some fine killing with my heavy gun. Very warm coming back

\section{Ducks}

Sept. 3

Eastman Gardener, Dick Florimey [?] and I went down to Wapsie looked like rain had a fine lunch then I went prospecting found some good Woodcock ground and quite a number of birds had to leave the ground quite early. Saw some partridge

Sept. 10

3 Woodcock 3 Pigeons 1 Duck

Juckett and I went to the Meradosha in our new boats Ducks very scarce Saw quite a good many pigeons flying went up in the bluffs

Sept. 10

1 Duck 1 Pigeon

Went to the Meradosha night before and slept in my boat. Hufman came down in Juckets boat worked very hard went up above. Quite a show of ducks but seemed to fly [illegible]

Sept. 24

\section{Ducks}

Went to the Meradosha night before mosquitoes both-

$25 \mathrm{By}$ three kinds of chickens Poyneer refers to three different ages of chickens, all hatched the same season, but in different periods in different broods.

26The prairie chicken is extremely scarce today too 
ered badly. The first flight ducks came last night but few moving in morning and those very high

Oct. 1

8 Ducks 2 Snipe

Went to the Meradosha night before saw a good many in going up killed $3 \mathrm{Teal}$. Very cold night stopped at the Willows early in the morning I moved over to the opposite side and had some fine shooting. It made Cory [?] and all the rest open their eyes at the distances my gun would kill them the wind got very high during the day. In the afternoon I moved down to the lower bend. Mallard came in pretty well but had to shoot to far. Frank did some good work

Came up after dark

Oct. $7 \& 8$

30 Ducks

Wm. Huffman and I drove up to Jas Burtons on the Meradosha wind blew very hard went down in front of McGrans quite a good show of birds in the evening did some long shooting. Frank did well flock of Geese passed my stand just as I left it out very early in the morning Ducks did not fly much worked around all day found a good point in some canes below McGrans. Came home early Monday morning

Oct. 15

27 Ducks 5 Snipe

Chas Welles \& I took Lafes team and drove down to the Wapsie one of the finest mornings I ever saw frosty I used Bob \& Charlie took Dash found quite a show of Snipe Bob did nicely expected to find a good show of Woodcock but they were scarce. Flora gave me a lively twist through the brush. Parker did some nice work

Oct. 22

15 Snipe 11 Ducks 3 Woodcock

Huffman, Jucket \& I started at 5 A.M. Wapsie. Dark \& muddy and every indication of rain no birds moving. came home early

12 Snipe 1 Woodcock 4 Ducks 


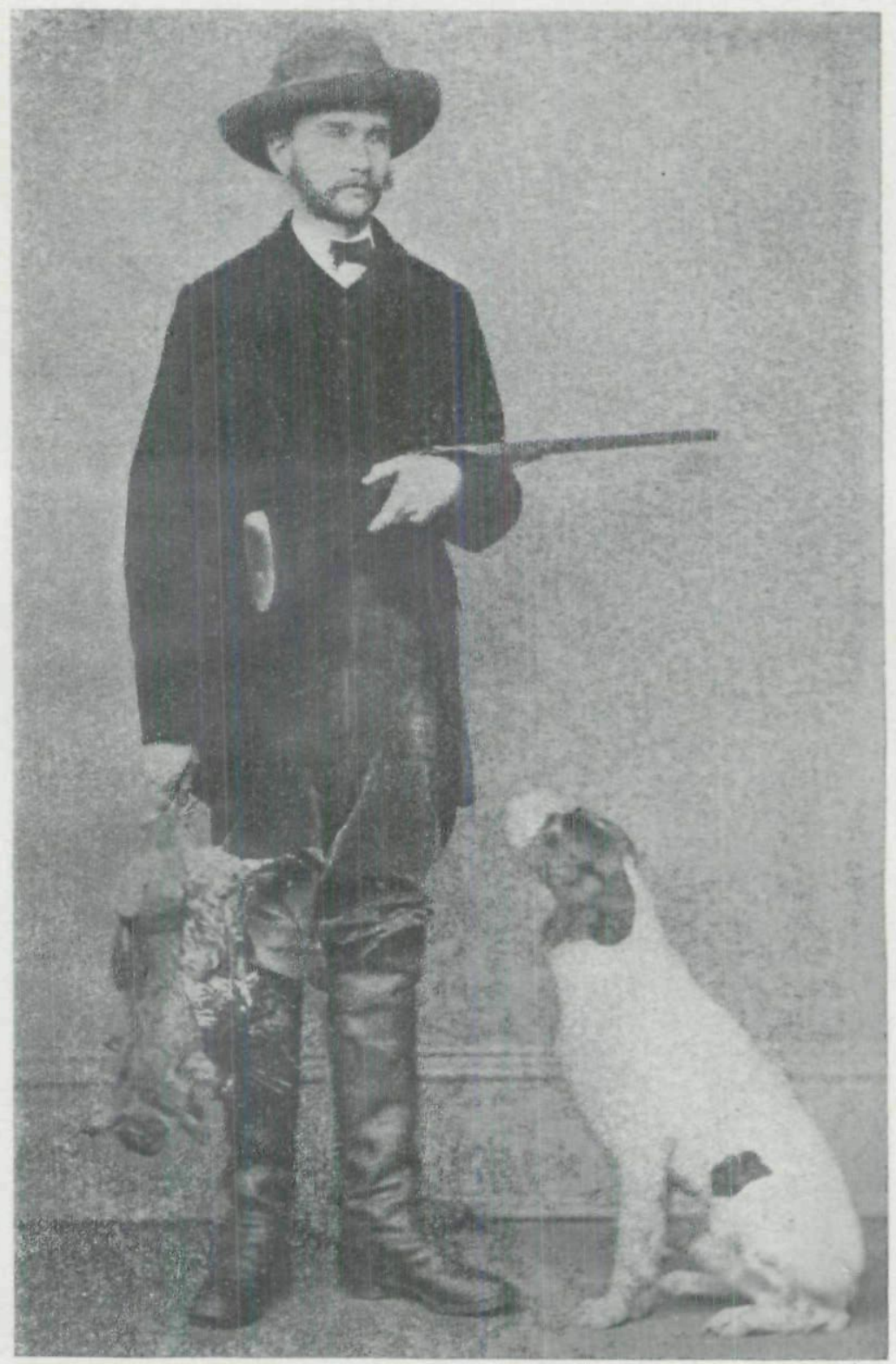

George E. Poyneer

GAME DIARIST 
Oct 29

Jucket I went down on Island no birds moving came home early

Nov. 2

Oscar Morton and I started for Gowrie at 5:30 Raining Geese \& Brant flying very thick all night and yesterday Did not see any ducks on the way out. Saw McNeil at Boone he will come on to morrow. Met a blower (?) ${ }^{2 \tau}$ on the train from Evanston found Col Magill \& Capt. Bid at Gowrie $^{2 s}$

Nov. 3

Col., Capt., Bid, John Evans, Oscar and I started out East of town saw a good many ducks after a little the Geese began coming I did not get in a good place. Morton had the best they were determined to come across him I had two shots and killed my first goose Frank retrieved it. Worked around the rest of the day jumping ducks had some fun the night flight did not amount to anything. Did some quick work on a Mallard Jumped him and killed him with 3rd shot

Nov. 4

Col \& Bid went home Dick joined us we went to Coon Slough I never saw so many ducks put the Bond Boat in the Slough if I had stayed there would have had a big time. But drove on out to Swansons John \& Oc went on The worst night I ever put in Ducks did not come into the corn

Nov. 5

Up early birds did not come into the corn and not many moving come to the conclusion that Swanson had been kidding us. drove over to Long Slough and there was myriads of Duck Geese \& Brant but could not get at them.

27 A braggert.

${ }^{28}$ Webster County. It will be noted that Poyneer and companions frequently used the trains to find the best shooting. 
Made an awful shot at a Brant. Went on and stopped to Smiths saw a great variety of Game Ducks Geese Brant Cranes \& Chickens in his cornfield all at one time. I made double shot on Sand Hills the ducks came in very plenty in the evening and we had glorious sport Frank improving every day. Stayed at Mr. Smiths and it was a fine place to stay

Nov. 6

15 Ducks 2 Sand Hill 1 Brant

Very cold everything froze up and I got froze our for the first time in my life Ducks moving very plenty and some Geese. Dick and I did some poor managing at the School House on Geese. In the afternoon I got a good place in Smiths cornfield and had some fine shooting.

"Ducks can smell"

\section{Ducks}

Nov. 7

"Election day" Gave up my vote for Tilden \& Hendrick ${ }^{20}$ for the sake of a hunt very few ducks went in below Smiths killed a large Sand Hill and how he did kick corn stalks. On the way into Gowrie stopped at different sloughs found Ducks \& Geese setting on the ice

4 Ducks 1 Sand Hill

Nov. 12

Went down to the Meradosha Water very low found a flock of Geese setting in the Dosha but they saw me first. Water very low. Used Bob went up in the bluffs after partridge

Nov. 19

1 Duck 1 Rabbit 1 Partridge 6 Snipe

Juckett and I went across the river after Quail got up three bevies had hard luck finding them afterwards. went down south after partridge

10 Quail 1 Partridge 3 Rabbits

29 Reference is to the presidential election of 1876 when Samuel J. Tilden and Thomas A. Hendricks ran on the Democratic ticket against Rutherford B. Hayes and W. A. Wheeler, Republicans. It was a fiercely fought election which was resolved only by an Electoral Commission, which gave the contest decision to Hayes. 
Nov. 26

Juckett and I went across the river It began snowing and drove us in

Dec. 3

2 Quail

Juckett and I went over toward Garden Plain found 5 Bevies I did some very poor shooting Went along CB\&Q track

Dec. 7

\section{Quail 3 Rabbits}

Juckett and I went over the river North of CB\&Q track made the longest tramp we ever made from here very cold and disagreeable found where Partridge had been in cornfield considerable snow on the ground. Bob did good work.

Dec. 31

17 Quail 1 Partridge 4 Rabbits

Juckett and I went down toward Albany found a nice lot of birds and some good ground I whittled one bevy Had Jeff out

1877

17 Quacil 1 Partridge

Feby

Bob \& Bill Hufman and I went to the Wapsie Ducks have been flying very plenty Ice all out did not fly much after we got there

2 Pintail (1 Mallard)

Juckett, Billy H. \& I went to the Wapsie all the sloughs frozen up No Ducks. Juckett killed a Hybrid

3 Mallard

April 1

Juckett, W. Hufman \& I went down to Lower Goose on Beaver Island wind blew very hard put decoys on East side wind so high had to move over on west side had some nice shooting came up on East side of Island

April 8

28 Ducks

Juckett, Hufman and I down to Folletts very few ducks has been some fine shooting there within the last week Col 
Magill and Tom got a fine bag it began raining soon after we got there. Juckett flushed some snipe they had just come in and were very wild. shot No. $4 \mathrm{~s}$ at them I killed the first of the season

11

\section{Snipe 4 Ducks}

Up on the bottom with Jeff would not work but little 2 Snipe

13

Up on bottom

15

1 Snipe

W Hufman Frank Eggleston \& I drove up to Hansons. birds very scarce I worked pretty well down

April 22

44 Snipe 6 Ducks

Juckett and I up to Hansons birds scarce

24 Snipe

July 1

Took Crippen boat went down to the mouth of the Wapsie hunted all the Islands for Woodcock found some nice ground water was too high used Fan and Jeff

10 Woodcock

8

Went in by Thomas well with Puss [?] hunted over a great deal ground did not find anything 15

Went on the Islands below Camache killed one Woodcock no birds

Aug. 15

1 Woodcock 3 Ducks

Lafe took Juckett and I went up to Dick Lyons got up two or three packs of birds when we came back at night got a pack near the house but was so dark could not do anything with them

22

9 Chickens

Went up to Hansons with Purdy \& Son used Jeff $\&$ Fan 
very warm. Jeff made his first point a chick Fan did nicely.

Aug. 29

\section{Chickens}

Started for Gowrie with Tom Magill Aug. 30

Grand Junction we hired a team and went out North found a very few birds Jeff improving Got up to Gowrie at $31 / 2$ P. M. John Evans was ready for us out we went and had a splendid shoot

\section{Chick}

31

Out early went South West had a splendid time did some nice [?] Jeff improving warm in the middle of day Had old Dash and Fan. They did not do much Fan being lame Lost my Rail Road tickets

\section{Chickens}

\section{Sept 1}

Took things easy went out a little while in the morning did not do anything to the house at dinner out in the evening

\section{Sept. 2}

\section{Chickens}

Out very early drove NW got on the ground before daylight very cold. Struck birds as soon as we started in. John $\&$ Tom followed a pack into the prarie. Jeff did some elegont work showing fine nose and staunch I found two packs and marked one down in the prarie. found them and killed them all jumped into the wagon and drove to new ground had splendid luck in finding I killed 5 out of one pack on first rise we all shot nicely and worked hard Old Jack did nice work. Got in quite late made the extraordinary bag of

\section{Chickens 1 Mallard}

Sept. 3

Started for the Hampton trials ${ }^{20}$ Tom took the dogs home

30Probably Hampton, Iowa. Poyneer was a well known judge of field trials in dog shows. The reader will note the different dogs mentioned in Poyneer's account, and his frequent comments on their performance. Since he was one of the judges, Poyneer naturally sent his own dogs home. 
and the birds they all kept nicely

Sept. 456 Hampton Trials

Sept. 9

Went down to the Wapsie with Purdy \& Sm. Used Shot, Jeff \& Fan. They worked nicely. Saw first Snipe

Sept. 16

1 Chick 3 Ducks

Went to Camache and crossed on the Ferry and drove up to Shlingers I was using a new Parker and did some poor shooting there was one of the finest flights of Blue wing Teal I ever saw near the point The rice was very high and the water was higher than last season

\section{Sept 22}

35 Ducks

Sent my boat down went to Shlingers and stayed all night very warm next day had some nice shooting about all at Teal

29

$$
35 \text { Ducks }
$$

Lot Smith and I stayed all night at Shlingers got some fair shooting at evening on the Point in the morning we worked down below rained most all day and all the way home

65 Ducks 
Copyright of Annals of Iowa is the property of State of Iowa, by \& through the State Historical Society of Iowa and its content may not be copied or emailed to multiple sites or posted to a listserv without the copyright holder's express written permission. However, users may print, download, or email articles for individual use. 